\title{
Getting Paid in the Naked Economy
}

Meredith R. Miller

Touro Law Center, mmiller@tourolaw.edu

Follow this and additional works at: https://digitalcommons.tourolaw.edu/scholarlyworks

Part of the Contracts Commons, and the Labor and Employment Law Commons

\section{Recommended Citation}

32 Hofstra Lab. \& Emp. L.J. 279 (2015)

This Article is brought to you for free and open access by the Faculty Scholarship at Digital Commons @ Touro Law Center. It has been accepted for inclusion in Scholarly Works by an authorized administrator of Digital Commons @ Touro Law Center. For more information, please contact Iross@tourolaw.edu. 


\title{
GETTING PAID IN THE NAKED ECONOMY
}

\author{
Meredith R. Miller*
}

The individual, not the organization, has become the economy's fundamental unit. Put more simply, we're all going Hollywood. ${ }^{1}$

"It's the end of work as we know it," reports the Accenture Institute for High Performance in a paper titled The Rise of the Extended Workforce. $^{2}$ The report predicts that, "[i]n the future, organizations' competitive success will hinge on ... workers who aren't employees at all." The legal nature of employment is changing and has been changing for quite some time; fewer and fewer workers are "employees."

It is not new or novel to recognize that, from a legal perspective, there are many benefits to employers who hire independent contractors rather than employees. ${ }^{5}$ Among many other advantages, employers may save costs by avoiding payment of mandated contributions for social security and unemployment taxes. ${ }^{6}$ Employers also save on discretionary fringe benefits such as sick leave and vacation time. ${ }^{7}$ In addition, employers have more flexibility: independent workers are not

* Associate Professor of Law, Jacob D. Fuchsberg Law Center, Touro College and principal of Miller Law, PLLC, which represents small businesses, freelancers and start-ups. I am thankful to Touro Law students Jenny Lynn Lazar and Christopher Miner for outstanding research assistance.

1. Daniel H. PINK, Free Agent Nation: How America's New INDEPENDENT Workers ARE TRANSFORMING THE WAY WE LIVE 17 (2001).

2. David Gartside, Yaarit Silverstone, Catherine Farley \& Susan M. Cantrell, Trends Reshaping the Future of HR: The Rise of the Extended Workforce, ACCENTURE INST. FOR HIGH PERFORMANCE 3 (Mar. 1, 2013), http://www.accenture.com/SiteCollectionDocuments/PDF/Accenture-Future-of-HR-Rise-ExtendedWorkforce.pdf.

3. Id.

4. See id.

5. See Stephen F. Befort, Revisiting the Black Hole of Workplace Regulation: A Historical and Comparative Perspective of Contingent Work, 24 BERKELEY J. EMP. \& LAB. L. 153, 154, 16263 (2003).

6. See id. at 163 .

7. Alan S. Gutterman, Business Transactions Solutions, adVantages of Using INDEPENDENT CONTRACTORS $\S 173: 17$ (Thomson Reuters, 2015). 
subject to the wage and overtime rules of the Fair Labor Standards Act and do not come within the protections of antidiscrimination laws. ${ }^{8}$ Further, independent contractors do not expose an employer to the risk of vicarious liability. ${ }^{9}$

There have long existed incentives for employers to characterize workers as independent. ${ }^{10}$ What is shifting, however, is the workers' narrative about independence. At least for creative and highly skilled workers, the changing narrative is one of free agency: ditching the man and charting your own course, which writers and entrepreneurs Ryan Coonerty and Jeremy Neuner have dubbed the "naked economy."11

Why is this economy "naked"? While acknowledging vulnerability, the reference to nudity appears to emphasize freedom: "stripping work bare" to reinvent it with the essentials required for productivity and satisfaction. ${ }^{12}$ This frame of mind places high value on control and flexibility. ${ }^{13}$ It eschews the rigid nine to five workday, with its commute and face time. ${ }^{14}$ It emphasizes work-life balance, changes in technology that allow for flexibility, and the dream of charting one's own destiny. ${ }^{15}$ All of these factors are coalescing to push people (at least, creative and highly skilled people) to choose independence. ${ }^{16}$

Independent work, however, has its drawbacks. One of the significant problems in the independent workforce is nonpayment of invoices. ${ }^{17}$ Forty percent of respondents to a Freelancers Union survey

8. See id:; Fact Sheet \#13: Am I an Employee?: Employment Relationship Under the Fair Labor Standards Act (FLSA), U.S. DEP'T LABOR WAGE \& HOUR DIV., http://www.dol.gov/whd/regs/compliance/whdfs 13.pdf (last revised May 2014).

9. See GUTTERMAN, supra note 7, § 173:28.

10. See id. § 173:17; see also 1 Policies AND PRACTICES § 29:11 (Thomson Reuters, 2015).

11. See RYAN COONERTY \& JEREMY NEUNER, THE RISE OF THE NAKED ECONOMY: HOW TO BENEFIT FROM THE CHANGING WORKPLACE 1-10 (2013); see also PINK, supra note 1, at 76-77.

12. See COONERTY \& NEUNER, supra note 11, at 2-3.

13. See id. at 4 (illustrating that the "naked" economy will allow people to set their own prices, work hours, and balance the many things going on within their lives).

14. See id. at 2-3 (listing several factors from the nine to five workday that "need to go"); see also Fabio Rosati, Foreword to RYAN COONERTY \& JEREMY NEUNER, THE RISE OF THE NAKED ECONOMY: HOW TO BENEFIT FROM THE CHANGING WORKPLACE, at ix (2013).

15. See COONERTY \& NEUNER, supra note 11 , at 3.

16. See The Successful Independent Contractor: $A$ Workforce Trend for the Future, CAREER ADVISORY BD. 1, 2-3, http://careeradvisoryboard.org/public/uploads/2014/06/Career-AdvisoryBoard-MBO-Executive-Summary_FINAL.pdf (last updated 2014).

17. Sara Horowitz et al., Freelancers Union, IndePendent, INNOVATIVE, AND UNPROTECTED: How THE OLD SAFETY Net is FAILING AMERICA'S NEW WORKFoRCE 1, 5-6, available at $\mathrm{http}: / / \mathrm{fu}-\mathrm{res}$. org/pdfs/advocacy/2010_Survey_Full_Report.pdf (last visited Feb. 22, 2014). There are, of course, other significant problems-for example, lack of access to unemployment insurance. $I d$. at $1-2$. This paper focuses more narrowly on the problem of unpaid invoices. See infra Part II. 
reported trouble collecting unpaid fees from clients. ${ }^{18}$ Of those respondents, $83 \%$ reported getting paid late, $33 \%$ reported never getting paid, and $28 \%$ reported getting paid less than billed. ${ }^{19}$

This article addresses independent workers' very specific and alltoo-common difficulties in getting paid. It is written for a mixed audience and is intended to be both practical and accessible. There is hope that it will further the academic conversation but is also written for attorneys, policymakers, and independent workers. Part I defines the naked economy and tracks the rise in independent work. Part II discusses the problem of nonpayment. Parts III, IV and V, respectively, provide an overview of the contractual tools, legislative reforms, and market responses that are evolving to minimize the risk of nonpayment.

\section{GETTING NAKED: THE RISE IN INDEPENDENCE}

A recent $\mathrm{MBO}$ Partners ${ }^{20}$ study reported a growth in independent work in the United States. ${ }^{21}$ The report estimated nearly 17.7 million independent workers in 2013, an increase of 5\% from 2012 and $10 \%$ from $2011 .^{22}$ The 2013 study projects there will be more than 24 million independent workers in the United States in 2018. "[A]n estimated 30 percent of those in today's job market - or roughly 42 million workersare either self-employed or part-time."24

Taken in a global context, a Princeton economist posits "that almost 30 percent of the jobs in the United States, including lawyers, accountants, and other traditional 'good jobs,' can be outsourced." ${ }^{25}$ The

18. HOROWITZ ET AL., supra note 17, at 5 .

19. Id. at 6 .

20. MBO Partners provides consulting platforms and research tools for independent consultants. See Our Company, About MBO, MBO PARTNERS, https://www.mbopartners.com/about-mbo-partners (last visited Feb. 24, 2012). It should be noted that MBO Partners has an interest in seeing increases in the independent workforce, the market for its services. See id.

21. See MBO PARTNERS, THE STATE OF INDEPENDENCE IN AMERICA 3 (2013), available at http://info.mbopartners.com/rs/mbo/images/2013-

MBO_Partners_State_of_Independence_Report.pdf [hereinafter MBO PARTNERS REPORT].

22. Id.

23. Id.

24. Rosati, supra note 14 , at $\mathrm{x}$-xi. It is worth recognizing that this book was written by a coworking space owner and Elance founder, people with a stake in seeing a growth in independent work. See id.

25. COONERTY \& NEUNER, supra note 11, at 15 (citing Alan Blinder, How Many U.S. Jobs Might Be Offshoreable? (Ctr. for European Policy Studies, Working Paper No. 142 41-78 Mar. 2007)). 
market research firm International Data Corporation estimates that "there will be more than 1.3 billion mobile workers-workers who can work from anywhere-by $2015, " 26$ which is $37 \%$ of the global workforce. ${ }^{27}$

\section{Who are "independent workers?"}

The MBO Partners study defines "independent workers" as "people who work at least $15+$ hours per week in non-traditional, non-permanent full or part-time employment and includes workers who identify themselves as consultants, freelancers, contractors, self-employed, and on-call workers, among others." ${ }^{28}$ The independent work force is, therefore, broader than those who consider themselves "freelancers.",29 In terms of legal categorization, independent workers are often likely to be independent contractors, but the category is wider than all independent contractors. ${ }^{30}$

Further, as used here, independent work is to be distinguished from what academics often describe more broadly as "nonstandard" or "contingent" work. ${ }^{31}$ The workers described here as "independent" are talented, highly skilled, and take on freelance or consulting work on a project by project basis-for example, in computer programming, engineering, or design. ${ }^{32}$

Against the backdrop of a global economy, weak domestic job market, and evolving technology, the narrative of independence is

26. Id. at 18 (citing Press Release, Int'l Data Corp., Mobile Worker Population to Reach $\$ 1.3$ Billion by 2015, According to IDC (Jan. 5, 2012)).

27. Id.

28. MBO PARTNERS REPORT, supra note 21 , at 17.

29. See id.

30. See Matthew Dimick, Labor Law, New Governance, and the Ghent System, 90 N.C. L. REV. 319, 372-73 (2012) (including independent contractors as only one type of independent worker); MBO PARTNERS REPORT, supra note 21, at 17.

31. See, e.g., Katherine M. Forster, Note, Strategic Reform of Contingent Work, 74 S. CAL. L. REv. 541, 546 (2001). Contingent work, sometimes called nonstandard work, is characterized by impermanence; it may be limited in duration, hours available, or job security. Definitions of these terms vary. "For example, the Bureau of Labor Statistics (BLS) characterizes contingent works as 'those who have no explicit or implicit contract and expect their jobs to last no more than a year." Id. (quoting Robert J. Grossman, Short-Term Workers Raise Long-Term Issues, HR MAGAZINE, Apr. 1998, at 81, 82). This definition is not very useful because, in light of employment at will, that is the vast number of workers in the US economy may be terminated at any time. See At-Will Employee $F A Q$ 's, FINDLAW, http://employment.findlaw.com/hiring-process/at-will-employee-faqs.html (last visited Feb. 22, 2015).

32. See Forster, supra note 31, at 547-48; MBO PARTNERS REPORT, supra note 21, at 3 (stating that independent workers bring skill and value to the business world they operate in). 
shifting for this highly skilled class of contractors: ${ }^{33}$ "As the myth of job security with a big company begins to fade, the American Dream will again recalibrate to something similar to what it originally was-the dream of being in charge of your own destiny." 34 It is the talent and skill these independent workers possess that permits them to recalibrate. ${ }^{35}$ In the "naked economy," they are encouraged to "ditch the man" and the confines of the traditional workplace. ${ }^{36}$

The highest value is freedom and this narrative emphasizes the benefits of independent work over its drawbacks. The term "naked" appears to acknowledge the vulnerability of independence: "[W]orkers may see the Naked Economy as just one more step toward leaving them and their family literally naked against the blizzards of a globalized economy." ${ }^{37}$ However, overwhelmingly, the focus is on the benefits of redefining work:

This is not about whether your rear end should be covered when it hits your office chair but whether it needs to be there at all. .. We believe that if we want to create jobs, increase our collective potential for innovation, and maybe even save the planet and our sanity, we need to completely rethink how we've organized our economy. And we need to start by stripping work bare. ${ }^{38}$

The promise of the naked economy is that the changes in

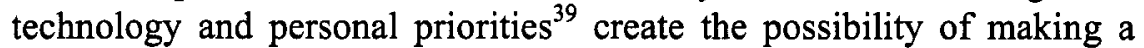
living while also making a life. ${ }^{40}$ The narrative of choice is focused on satisfaction and, by MBO Partners's measures, independent workers

33. See MBO PARTNERS REPORT, supra note 21, at 15-16 (stating that "businesses will continue to turn to independent workers to meet their needs for agility and flexibility due to an increasingly volatile, complex, competitive, and always-changing global economy," and that this "structural shift towards independent work, coupled with the weak economy and a volatile job market, means going independent is, in many cases, the best career option"); see discussion supra pp. 279-80.

34. COONERTY \& NEUNER, supra note 11 , at 16.

35. See MBO PARTNERS REPORT, supra note 21 , at 16 ("Workers are more jaded about traditional work, but more optimistic about themselves. Both independents and non-independents say they're confident they have the ability to go independent and feel that they can bring to the table skills that were undervalued by previous employers.").

36. See PINK, supra note 1, at 69-70.

37. COONERTY \& NEUNER, supra note 11 , at 6 .

38. Id. at 2 .

39. See id. at 3 .

40. See, e.g., id. at 217-20 (illustrating two examples of people who are making a living while also making a life). 
have a high level of satisfaction with work. ${ }^{41}$

\section{Getting PAID: Collecting ON Invoices}

The narrative of free agency acknowledges but tends to downplay the vulnerability of independent work and, in particular, the common frustration of collecting unpaid invoices. ${ }^{42}$ The stories about nonpayment are familiar among independent workers: the client changes what they want, the client is purchased by another company, the client changes management, the client loses a big customer, the client has cash flow problems, or the client simply disappears without explanation when payment is due. $^{43}$ These are just a sampling of the tales of woe that leave independent workers without promised payment, most often after they have done a substantial amount of work. ${ }^{44}$ These are such common occurrences that colorful videos chronicling the problem of nonpayment-"F*ck You, Pay Me",45 and "What it Feels Like to be a Freelancer" ${ }^{46}$ - have gone viral. ${ }^{47}$

The struggle to get paid is not simply anecdotal. In 2010 , more than 3,000 independent workers from across the United States responded to a poll by the Freelancers Union. ${ }^{48}$ These workers represented a variety of industries: graphic design, web design/development, accounting/bookkeeping, marketing, film/television, publishing/information services, advertising, education/training, health care/hospitals, among others. $^{49}$ In the preceding year, $40 \%$ of these independent workers reported trouble getting paid on invoices. ${ }^{50}$ Of those respondents who had trouble getting paid, $83 \%$ were paid late (after the agreed-upon date). ${ }^{51}$ Cumulatively, the respondents were owed over $\$ 3,000,000$; the average survey respondent was owed nearly

41. See MBO PARTNERS REPORT, supra note 21, at 15 .

42. See Horowitz ET AL., supra note 17, at 5-6.

43. See San Francisco Creative Mornings, $F^{*} c k$ You. Pay Me, Vimeo (Mar. 25 2011), http://vimeo.com/22053820.

44. See HOROWITZ ET AL., supra note 17, at 5-6.

45. San Francisco Creative Mornings, supra note 43

46. DontGetScrewedOver, What it Feels Like to be a Freelancer, YouTUBE (July 31, 2012), https://www.youtube.com/watch?v=-1Y9N18QrOA (being viewed more than 308,399 times).

47. See, e.g., id.; San Francisco Creative Mornings, supra note 43.

48. HOROWITZ ET AL., supra note 17, at 2. "The majority live in New York $(47 \%)$ or California (14\%). Ninety-two percent are independent contractors, with others being temporary or part-time workers." Id.

49. Id.

50. Id. at 5 .

51. Id. at 6 . 
$\$ 6,000 .^{52}$ They spent considerable time attempting to collect paymenta cumulative total of more than 17,000 hours. ${ }^{53}$ While many resorted to repeated calls and emails requesting payment, only $4 \%$ hired an attorney and a mere $2 \%$ took the client to small claims court. ${ }^{54}$

Independent workers often have very little leverage to demand timely payment and the companies that hire them often have very little incentive to pay on time. ${ }^{55}$ Indeed, the mismatch often reflects the same imbalance of bargaining power noted as the hallmark of the employeremployee relationship. ${ }^{56}$ Yet, most independent workers are independent contractors and, therefore, are not considered "employees" in the eyes of the law. ${ }^{57}$ This means that the legal mechanisms erected to protect employees do not extend to independent workers, including the mechanism of filing a claim with a state administrative body for unpaid wages. $^{58}$

\section{GetTing Protected: Contracts}

The shift to an independent workforce necessitates that the norms of contracting also shift. ${ }^{59}$ However, taking a broad view, contracting practices do not yet appear to have met the challenges of independent work. $^{60}$ There is some promise in emerging technology that assists independent workers in creating contracts. ${ }^{61}$ As the norms shift, it is possible that the process of negotiating the contract, whether or not facilitated by technology, will be recognized as a way for independent worker and client to strengthen their relationship. ${ }^{62}$

52. Id. at 5 .

53. $I d$.

54. Id. at 7.

55. Id. at 6 .

56. See Aditi Bagchi, The Myth of Equality in the Employment Relation, $2009 \mathrm{MICH}$. ST. L. REV. 579, 580-81 (2009).

57. See HOROWITZ ET AL., supra note 17, at 2 (explaining how independent workers do not have the safety nets that a traditional employee has).

58. See id. at 7.

59. See id. at 1 ("The American workforce has changed forever; independent workers (freelancers, temps, independent contractors, part-timers, and the self-employed) now make up onethird of the workforce in the United States.").

60. See id. at 7 .

61. See, e.g., Freelancers Union Contract Creator, FREELANCERS UNIONS (last visited Jan. 20, 2015), https://www.freelancersunion.org/contract-creator (providing a free online template contract for freelance workers).

62. See Vinay Jain, "Making the Client Part of the Process"-Freelancing Tips from a Lawyer, SHAKE (July 23, 2014), http://www.shakelaw.com/blog/make-client-part-of-the-processfreelancing-tips-lawyer/. 
With a lack of regulatory protections when facing nonpayment, the role of a written contract takes on heightened importance for independent workers. ${ }^{63}$ Two telling data points stand out from the Freelancer Union survey: "only $33 \%$ of respondents always use written contracts when working with clients" and only $4 \%$ of respondents have hired an attorney to assist in collecting unpaid invoices. ${ }^{64}$ Very few attorneys are going to chase payment when there is no written contract. Even when there is a written service agreement, even fewer attorneys are going to chase payment when their own fee would exceed the unpaid balance on an invoice.

Independent workers need to use written contracts; with a written contract, there are mechanisms to minimize the risk of nonpayment. ${ }^{65}$ Not only is it important that an independent worker have a written contract with the client, but the terms of that contract must provide leverage to demand payment if it is not made in a timely fashion. ${ }^{66}$

Every independent worker should have a written services agreement that addresses the following questions:

- Who is the client?

- What is the scope of project?

- What are the deadlines?

- How is the fee calculated?

- When is payment due?

- What is the method of payment?

- What happens if the contract is terminated?

- What expenses will be reimbursed?

- Who owns any intellectual property that is created?

- Where and how are disputes to be resolved? ${ }^{67}$

63. See HOROWITZ ET AL., supra note 17, at 7 (showing the lack of coverage for independent workers under labor laws and how contracts can help).

64. Id.

65. See Meredith Little, Independent Contractors: Make Sure Your Contract Protects Your Interest, TECHREPUBLIC (Mar. 13, 2009), http://www.techrepublic.com/blog/itconsultant/independent-contractors-make-sure-your-contract-protects-your-interests/; Amber Leigh Turner, You Need These Must-Have Clauses in Your Freelance Contracts, THENEXTWEB.COM (Oct. 14, 2012, 12:00 PM), http://thenextweb.com/entrepreneur/2012/10/14/you-need-these-must-haveclauses-in-your-freelance-contracts/ (noting clauses that should be included in a contract for a freelancer).

66. See Little, supra note 65; Daphne Mallory, 4 Independent Contractor Laws that Protect You, WAHM.COM, http://www.wahm.com/articles/4-independent-contractor-laws-that-protectyou.html (last visited Jan. 22, 2015).

67. These questions and suggested contract terms are largely culled from personal experiences representing independent workers. They are, in one way or another, echoed by advice available on 


\section{A. Who is the Client?}

If the client is a company, not an individual, that should be clearly stated. In that case, the individual acting on behalf of the company should be identified by title with the company. This is important because the contract will only be binding if the client's representative has authority to enter into the deal. ${ }^{68}$ Similarly, if the independent worker has formed a company (e.g., a corporation or LLC), the company should be the party to the contract, not the independent worker in an individual capacity. This will assist the independent worker in avoiding personal liability for any debts or obligations that might arise under the contract. $^{69}$ For example, Joe Smiley is a freelance copywriter. He has formed Joe Smiley Copywriter, LLC and is the only owner of his business. Joe's service agreement should be between his LLC and his client.

\section{B. What is the Scope of Project?}

The scope of the project should be specified, including defining terms and clearly stating expectations. The scope of the project should answer who, what, where, when, why and how of the project. The parameters of the project should be stated expressly. For example, where possible, the copywriter Joe Smiley should specify subject matter

the Internet that makes up the common wisdom of contracting for independent workers. See, e.g., 8 Contract Provisions Every Freelancer Should Know, FreELANCERS UNION (Sept. 11, 2013), https://www.freelancersunion.org/blog/2013/09/1 1/8-contract-provisions-every-freelancer-shouldknow/; NicoleD, Setting Up a Client Contract: Must Know Information for Freelancer, U.S. SMALL BUS. ADMIN., http://www.sba.gov/community/blogs/community-blogs/business-lawadvisor/setting-client-contract-must-know-information-f (last updated Jan. 16, 2015); Alyssa Gregory, Kill Fees and Six Other Clauses to Consider for Your Contract, SITEPoINT.CoM (Aug. 28, 2009), http://www.sitepoint.com/clauses-to-include-in-freelance-contract/; Keep out of Trouble: 4 Crucial Things All Freelance Contracts Need to Include, IDEALISTS BLOG (Nov. 10, 2013), https://blog.theidealists.com/pro-tips/4-crucial-things-that-all-freelance-contracts-need-to-include/; Little, supra note 65; Mallory, supra note 66; Viktor Marinow, 5 Must-Have Clauses for any Freelancer Contract, FREELANCERMAP.COM (Dec. 5, 2014), http://www.freelancermap.com/freelancer-tips/7918-5-must-have-clauses-for-any-freelancercontract; Samar Owais, 8 Contract Clauses You Should Never Freelance Without, HONGKIAT.COM, $\mathrm{http} / /$ www.hongkiat.com/blog/freelance-contract-clauses/ (last visited Jan. 22, 2015); Kelly Palaganas, Freelance Contracts: Important Clauses and Example, PANDADESK.COM (Feb. 6, 2012), http://pandadesk.com/blog/2012/02/freelance-contracts/; Donald Ritchie, Freelance Contracts: Covering the Essentials, HEXCENTRAL.COM (Mar. 2013), http://www.hexcentral.com/articles/contracts-2.htm.

68. See Turner, supra note 65.

69. See id. 
and word or page count. By way of another example, a web designer will want to specify the subject matter of the site and a maximum number of pages, including the client's right to mock ups and revisions. The more detailed the description, the better. Further, the description of the project should be specific enough that it is possible to measure whether it has been satisfactorily completed. This has two components. One, the task must be defined such that it can be determined whether the task has been performed to the specified levels of quality and quantity. ${ }^{70}$ Two, the contract must clearly define when the project is complete. ${ }^{71}$

\section{What are the Deadlines?}

It is important to specify the dates the work is promised, as well as the dates for the client to provide feedback. ${ }^{72}$ This plan for the project should include a final deadline for completion. A logo designer might agree to provide three renderings by a date certain and provide that the client has ten days to provide feedback. The logo designer might agree to another round of drafts on a date certain, with another ten days for the client to choose one proposed logo and ask for any revisions. The contract should provide a date certain when the project is completed. Setting a schedule attempts to prevent the client from sitting on the work (and, with that, delaying the project and payment for the work). It also supplies a definition of when the work is "complete."

\section{How is the Fee Calculated?}

Will the client be charged on an hourly basis? Who is working on the project and are all workers billed at the same hourly rate? What is the billing increment-six minutes (i.e., tenths of an hour) or fifteen minutes (i.e., quarters of an hour)? Will there be an hourly basis with a cap? Is it a flat fee project? The fee terms should be set forth in painstaking detail to avoid a dispute about what the client owes on the project.

70. See Little, supra note 65; Turner, supra note 65.

71. 8 Contract Provisions Every Freelancer Should Know, supra note 67.

72. See id. (explaining the importance of deadlines for both the client and the freelancer); Marinow, supra note 67 (discussing how deadlines are a motivating factor for finishing the contract). 


\section{E. When is Payment Due?}

The agreement should address when billing statements will be sent to the client and when payment is due. If the project is being billed by the hour, the invoices should be sent on a regular basis (a date or day certain) and payment should be due within a certain number of business days. If the project is for a flat fee, the payments should be keyed to progress on the project. Just by way of example: $25 \%$ due before work begins, $25 \%$ due upon completion of first draft, $25 \%$ due after first round of revisions, and final $25 \%$ payment due upon completion. The contract should set out milestones relevant to the project and tie payments to those milestones, reserving the right of the independent worker to retain payments made and discontinue work in the event that the client does not make a progress payment. Whether on a flat rate or hourly basis, the independent worker should always take a nonrefundable deposit before beginning the project. A client who cannot pay some portion of the bill (or estimate) up front is not likely to pay the entire bill later. ${ }^{73}$ Finally, contracts often specify late fees, usually based on a percentage of the outstanding amount due. ${ }^{74}$ A client who wants to avoid late fees might be incentivized to pay on time, so it certainly does not hurt to add this provision to the contract.

\section{F. What is the Method of Payment?}

It is worthwhile to specify how payment will be made, especially if the independent worker wants to receive payment via an electronic service. For repeat clients, or clients with long running projects, the independent worker should consider obtaining the right to automatically charge a credit card on file when project milestones are accomplished. For example, an independent computer professional might enter into service contracts with clients to provide unlimited supported for a monthly fee. For these clients, the professional should contract for the right to charge the clients' credit cards on file on the first of each month for that month's service. This avoids the problem of the client simply not paying with the explanation that she did not need computer services that month-when the agreement is that, for the fee, the professional is

73. See Jay Foonberg, "Foonberg's Rule" CASH UP FRONT, YOUTUBE (Mar. 26, 2007), https://www.youtube.com/watch? $v=0$ omRgofemi-I. Lawyers know this as "Foonberg's Rule," which is 3 words: "cash up front." Id.

74. See, e.g., 8 Contract Provisions Every Freelancer Should Know, supra note 67. 
agreeing to make herself available without further charge. ${ }^{75}$

\section{G. What Happens if the Contract is Terminated?}

If a client is not making promised progress payments, the independent worker should reserve the right to keep any payments made and terminate her services. What should happen if the client cancels or delays the project? In most cases, the contract should provide for a "kill fee." This is a fee the client promises to pay if the project is cancelled through no fault of the independent worker; it is often expressed as a percentage of the total fee. ${ }^{76}$ The amount of the fee should compensate the worker for the time they expended or set aside for the projectsomewhere between 25 and $50 \%$ of the balance owed, though perhaps more depending on the size and nature of the project. The contract should not describe the fee as a "penalty" and should not be grossly disproportionate to the business loss to the worker because it then risks not being enforced in court. ${ }^{77}$

\section{H. What Expenses Will be Reimbursed?}

The service agreement should identify expenses that the client will reimburse. This is especially important if the project requires purchasing or leasing equipment, acquiring raw materials, paying for copying, printing, postage, or significant travel. If expenses are reimbursed, the contract should set a deadline for payment. It should also specify whether advance client consent is required before expenses are incurred.

\section{Who Owns any Intellectual Property That is Created?}

If the project will result in a work that contains original copy, design, engineering, coding, or other creative input, the contract should

75. See id. (explaining the different payment schedules and methods used by freelancers); Marinow, supra note 67 (discussing the importance of articulating and clarifying all expectations in a written contract).

76. See, e.g., 8 Contract Provisions Every Freelancer Should Know, supra note 67 (highlighting the importance creating clauses to protect from early termination); Marinow, supra note 67 ("If you happen to have bad luck with your client, a kill fee is often a clause that will save you from not getting all the money you have earned.").

77. See RESTATEMENT (SECOND) OF CONTRACTS $\S 356(1)$ (1981) (stating that liquidated damages that work as a penalty will not be enforced). 
state who owns the rights to the work (i.e., whether the rights are maintained by the creator or transferred to the client). Even when title in the creative work is retained by its independent author, the client will want the right to use it (that is, after all, at least part of what the client is paying for). ${ }^{78}$

Rather than get into a discourse on intellectual property licenses, about which much has been written, it is important to note how this connects to getting paid. The contract should specify that any assignment of rights to the client is not effective until payment in full is made. This is especially useful to mitigate the risk of nonpayment where the independent worker is hired on a creative project that includes payments tied to rounds of revisions. ${ }^{79}$ For example, assume Carol is hired to design a logo for a company and they agree that payments will be based upon progress. The client pays Carol $20 \%$ of the total flat fee as a nonrefundable deposit. She receives another $20 \%$ upon delivery of three draft logos. Carol hits a home run and one of the draft logos is perfect. The client might begin using it and disappear without paying the remaining $60 \%$ of the fee. If, however, a provision in the contract provides that the client's rights in the logo do not vest until payment is made in full, Carol has a claim for infringement, a costly headache the client does not want. This substantially reduces the chance that the client will start using the logo until payment is made in full.

\section{J. Where and how are Disputes to be Resolved?}

Neither party wants a dispute concerning payment, and by addressing the process for resolving disagreements in a written contract the parties may actually work to prevent what would otherwise become a protracted dispute. The contract should choose a local forum and the applicable law. Most importantly, it should contain an attorneys' fee clause, providing that the client agrees to cover fees and litigation costs if the independent worker prevails in a dispute related to the client's nonpayment of fees. This clause is absolutely essential because it makes hiring an attorney to collect on invoice no longer a "zero sum game." That is, no invoice is too small to justify hiring an attorney. ${ }^{81}$ Where a

78. See Marinow, supra note 67 (stating the importance of including a copyright clause in the agreement); Turner, supra note 65 ("If you own the work, then you should detail how the client can use your work.").

79. See Turner, supra note 65.

80. See id.

81. See id. (explaining how attorneys will want to add how their fees are handled). 
$\$ 5000$ invoice would not have been worth hiring an attorney to pursue because of the fees, now the client has to pay those fees. The client also faces a big bill when the attorneys' fees are tacked on to the unpaid invoice, so the client might be incentivized to pay the balance due to avoid any further costs.

\section{K. Other Provisions}

There are additional, important provisions that serve to manage risk but do not necessarily relate to payment-warranties, indemnities, and confirmation of "independent contractor" status. ${ }^{82}$ There may also be provisions about confidentiality, solicitation, and competition. ${ }^{83}$ Many of these terms would likely be standard from client to client. ${ }^{84}$

\section{Creating the Contract}

As for creating the contract, the best case scenario is that the independent worker have an attorney draft a tailored, "fill in the details" service agreement to be presented to a client before work begins. If it avoids even one dispute, it was a worthwhile investment. In some instances, the work will be done for a big company that has its own "independent contractor agreement," in which case the independent worker may not have the bargaining leverage to request all of the terms outlined above. ${ }^{85}$ At the very least, the terms of payment should be benchmarked to progress on the project and any claims to intellectual property rights should be clearly understood.

For independent workers creating their own contracts, the process is now facilitated by technology. ${ }^{86}$ While it certainly is not a substitute for having an attorney appropriately tailor a service agreement to a worker's

82. See, e.g., Gregory, supra note 67 (showing how an indemnification clause "protects you as the contractor from future losses or damages experienced by the client"); Turner, supra note 65 (stating that other provisions can be considered, such as warranties).

83. See, e.g., Turner, supra note 65 (detailing how a clause about confidentiality will protect business practices).

84. See id. (emphasizing how these clauses are "must-have[s]" in freelance contracts).

85. See Owais, supra note 67 (outlining how a "single point of contact"" will allow you to negotiate with one person at a big firm, decreasing the disagreements in negotiating the contract); Palaganas, supra note 67 ("Ideally, you should always have a contract prepared for your clients. But, sometimes, clients provide their own documents.").

86. See, e.g., Create Your Free Independent Contractor Agreement, ROCKET LAWYER, https://www.rocketlawyer.com/form/independent-contractor-agreement.rl (last visited Feb. 24, 2015). 
particular business needs, it is likely that a generic contract is better than no contract at all. For example, Docracy provides an online repository of sample contracts. ${ }^{87}$ ShakeLaw is a mobile app that, based on answers to a series of questions, prepares a written contract. ${ }^{88}$ The Freelancers Union also provides an online contract creator. ${ }^{89}$

\section{GETTING PRoteCted: LEGAL REFORMS}

It is imperative that the law catch up to the naked economy to provide protections to the growing independent workforce. ${ }^{90}$ As of this writing, only one state has proposed a bill to address the problem of nonpayment. $^{91}$ In New York, the Freelancer Payment Protection Act (the "Payment Act" or the "Act") was passed in the Assembly but has not yet been voted out of Committee in the Senate. ${ }^{92}$ The Payment Act would revise the New York Labor Law to address the problem of unpaid invoices-namely, by:

- requiring "independent contractors" to be compensated within a reasonable amount of time;

- incentivizing the parties to define the terms of the engagement in a written contract;

- empowering the Department of Labor to recoup unpaid invoices and take action to pursue violations of written agreements; and

- setting penalties for clients who violate the Act. ${ }^{93}$

The Payment Act would define an "independent contractor" as "a sole proprietor who is not an employee and who is hired or retained by a client for an amount equal to or greater than six hundred dollars."94 The Act would require a client to pay compensation earned pursuant to a

87. Docracy-Free Legal Documents, DOCRACY, http://www.docracy.com/ (last visited Feb. 24, 2015).

88. Shake-Free Legal Agreements, SHAKELAw, http://www.shakelaw.com/ (last visited Feb. 24, 2015).

89. Freelancers Union Contract Creator, FREELANCERS UNION, https://www.freelancersunion.org/contract-creator/ (last visited Feb. 24, 2015).

90. See Befort, supra note 5, at 154, 171-77 (highlighting various areas of the law where contingent workers are not protected when employees are).

91. What You Need to Know About the Freelancer Payment Protection Act, THE HIRED GUNS (Feb. 6, 2012), http://www.thehiredguns.com/blogs/2012/02/06/what-you-need-to-know-about-thefreelancer-payment-protection-act/.

92. See S. 4129, 235th Leg., 2011-2012 Reg. Sess. (N.Y. 2011).

93. Id.

94. Id. $\S 196-\mathrm{B}(2)$. 
written contract on the terms set forth in that contract; ${ }^{95}$ however, in no event would payment be due "later than the last day of the month following the month in which the compensation [was] earned." 96 The Act would require that the agreed terms of work be in writing, signed by both client and independent contractor, and "kept on file by the client for a period of not less than six years." the written terms available to the Department of Labor and is unable to do so, it is presumed that the terms are as stated by the independent contractor. ${ }^{98}$

The Act would allow the independent contractor to file an administrative claim with the Department of Labor for unpaid compensation. $^{99}$ This mechanism is presently unavailable to independent contractors because they are not considered "employees" under the existing Labor Law. ${ }^{100}$ In that administrative proceeding, the client would bear the burden of proving that payment was made. ${ }^{101}$ Significantly, where the independent contractor prevails, the Department of Labor would be required to assess an additional amount up to $100 \%$ of the total amount due as liquidated damages. ${ }^{102}$ Moreover, the independent contractor would be entitled to prejudgment interest and attorneys' fees. ${ }^{103}$

There are a few significant features of the Payment Act that could be very effective to address the problem of unpaid invoices. The burden placed on the client incentivizes the parties to have a written agreement and, with that, has the potential to shift the norms-so that more than the current one third of freelancers will begin using written contracts as a regular business practice. ${ }^{104}$ Further, the mechanism of an administrative complaint that carries liquidated damages and attorneys' fees provides leverage for independent workers to demand payment. ${ }^{105}$

That said, there is some room to improve the Payment Act. First and foremost, the definition of "independent contractor" is too narrow

95. See id. § 196-B(1). "Compensation" is defined as an independent contractor's earnings and reimbursable expenses. Id.

96. See id. § 196-C(1).

97. Id.

98. See id.

99. Id. § 196-C(3).

100. See N.Y. LaBOR LaW § 196-b(2) (McKinney 2011).

101. See S. 4129 \& 196-C(4).

102. Id. $\S 196-\mathrm{C}(5)$.

103. Id.

104. See supra notes 63-64 and accompanying text.

105. See S. 4129 \& 196-C(5). 
because it applies only to sole proprietors. ${ }^{106}$ This means that, if an independent worker incorporates or forms an entity to protect herself from personal liability (e.g., a limited liability company or corporation), she has lost the opportunity to file a claim with the Department of Labor in the event that she is unable to collect unpaid invoices. Often, larger companies want freelancers to incorporate because it furthers the appearance that they are independent and, therefore, not misclassified as independent contractors. ${ }^{107}$ Therefore, a number of independent workers who, whether at the urging of clients or in seeking to limit their own personal liability, form a limited liability entity, will be precluded from using the mechanisms provided by the proposed Act.

Second, the Act would only apply to sole proprietors hired for $\$ 600$ or more. ${ }^{108}$ Setting aside the ambiguity whether the $\$ 600$ is per project or a sum total of the compensation for all projects for which the independent contractor has been hired, it is unclear why this threshold is even necessary. ${ }^{109}$ Indeed, should not a $\$ 400$ project have the same avenue for redress? This type of statute has the ability to raise the standards for all independent workers, not just those who are highly compensated. ${ }^{110}$

Finally, with the evidentiary presumption against the client in the absence of a written contract, ${ }^{111}$ it seems that the onus is on the client and not the independent worker to prepare a written contract. Independent work is performed in a wide variety of settings. ${ }^{112}$ For the bigger companies contracting out projects, it is likely that many are already preparing written independent contractor agreements for projectbased work. The need to shift norms to written contracts is most acute where independent workers are hired by smaller companies with access to fewer resources. ${ }^{113}$ In this scenario, it benefits the independent

106. See id. §196-B(2).

107. See Joseph T. Bartulis, Jr., A Quick Look at the Rigid Massachusetts Independent Contractor Law, FLETCHER TILTON PC, http://www.fletchertilton.com/pdf/business-corporatearticles/Rigid\%20Massachusetts\%20Independent\%20Contractor\%20Law.pdf (last updated May, 2012).

108. See S. 4129 at $\S 196-\mathrm{B}(2)$.

109. See id. (failing to explain why the threshold is set at six hundred dollars).

110. Indeed, it appears that these limits could be attributed to the construction contractor lobby. A revision to the definition of "independent contractor" was made to expressly state that it does not include construction contractors. It could be that this industry was concerned about wage claims by day laborers or other independent workers hired temporarily for construction projects.

111. See S. 4129 at $\S 196-C(4)$.

112. See supra Part I.A.

113. See Rick Suttle, The Advantages of a Large Business, DEMAND MEDIA, http://smallbusiness.chron.com/advantages-large-business-21007.html (last visited Feb. 18, 2015) 
worker to be the party that presents a standard written contract for services. ${ }^{114}$

Given that the presumption benefits the independent worker, the Act incentivizes the client to prepare a written contract. ${ }^{115}$ This is problematic for at least two significant reasons. First, a norm shift where independent workers prepare written service agreements will better protect them because they have more of a chance to control the terms. ${ }^{116}$ Second, the independent worker is a "repeat player," at least in the sense that he/she is experienced in the relevant market for the transaction. ${ }^{177}$ This should be used to the independent worker's advantage.

In other words, the independent graphic designer has a better sense of the potential pitfalls and ways she needs to be protected by contract than the dental practice that has hired her for its rebranding effort. It may be counterintuitive but the statutory presumption of contract terms is apparently favorable to the independent contractor; the independent contractor is better off with the statutory incentive to draft a written contract. A service agreement prepared by the independent worker is more likely to have the protections outlined above than a contract drafted by a one-off client and, as the contracting norms shift, the cost is minimal because the worker will have a standard service agreement on file.

\section{GeTtING PROTECTED: MARKET ForCES}

Where the law leaves off, market responses, often fueled by technology, have provided some hope of improving the prospects of payment. $^{118}$ Independent workers with outstanding invoices have taken

(showing larger companies have more resources and are capable of maintaining and keeping track of the documentation of a larger workforce).

114. See $i d$. (showing that a large company can handle keeping track of documentation, so when an independent contractor is dealing with a small company it would be smart for it to provide the documentation).

115. See S. 4129 at $\$ 196-\mathrm{C}(4)$.

116. See Marc Galanter, Why the "Haves" Come Out Ahead: Speculations on the Limits of Legal Change, 9 LAW \& SOC'Y REv. 95, 98 (1974) (discussing the legal advantages for the party who wrote the contract).

117. See id. The term "repeat player" is derived from Professor Marc Galanter's typology of litigating. Id. There, roughly, he described the "repeat player" as one that anticipates litigation and has resources and experience to its advantage. Id. He compared the repeat player to the "one shotter," who is comparatively disadvantaged in terms of resources and has only occasionally experienced litigation. $I d$. at 97 .

118. See, e.g., Freelancers Union, THE WORLD's LONGEST INVOICE, 
to the Internet with old fashioned "naming and shaming" in attempt to mar the reputation of deadbeat clients. 119 So-called "walls of shame" have surfaced on the Internet, complaining about client nonpayment, among other things. ${ }^{120}$ Without naming the clients, the Freelancers Union held an educational campaign where it hosted "the world's longest invoice," with a grand total of over $\$ 15,000,000$ owed in invoice amounts of all sizes. ${ }^{121}$

Websites that facilitate project-based hiring also provide some promise because they hold funds in escrow. ${ }^{122}$ For example, Elance provides a website where clients post projects and independent workers "bid" on them by submitting proposals. ${ }^{123}$ When deciding who to hire, the client may review the proposal, work samples, and the worker's profile page. ${ }^{124}$ Once hired, a shared "workroom" is created which "is a private online workspace that facilitates collaboration and tracks communication." 125 The site offers payment protection through an escrow service for flat fee projects. ${ }^{126}$ This way, the independent worker knows that the funds are available for payment when the project is completed. The payments are released from escrow when job milestones are reached and Elance states that it will assist the parties in resolving the dispute before releasing the funds, if a dispute should arise. $^{127}$ Similarly, the site Escrow.com offers milestone escrow services, ensuring that payment is available and will be released as stages of a project are completed. ${ }^{128}$

As technology evolves, making payment systems more sophisticated, the need for an escrow agent might even be eliminated.

http://www.worldslongestinvoice.com/ (last visited Feb. 18, 2015) (providing a website for freelancers to post their unpaid bills and stories) [hereinafter THE WORLD'S LONGEST INVOICE].

119. See, e.g., Karen E. Klein, A Risky Way to Get Deadbeat Clients to Pay: Shame Them Online, BLOOMBERG BUSINESS (June 10, 2014), http://www.bloomberg.com/bw/articles/2014-0610/a-risky-way-to-get-deadbeat-clients-to-pay-shame-them-online.

120. See id.

121. THE WORLD'S LONGEST INVOICE, supra note 118.

122. See Mark, How Does Elance Work, and How Much Does it Cost?, ELANCE (June 22, 2011, 8:45AM), http://archive.today/iJTk.

123. See id.

124. See id.

125. See id.

126. See id.

127. See What is Elance Escrow Payment Protection for Freelancers?, ELANCE, http://help.elance.com/entries/23449696-What-is-Elance-Escrow-Payment-Protection-for-

Freelancers- (last visited Feb. 27, 2015).

128. The Assurance Behind the Shield, ESCROW.COM, https://www.escrow.com/services/milestone-escrow.aspx (last visited Feb. 27, 2015). 
For example, developments may make "smart contracts" possible, which would reduce the risks of nonperformance or nonpayment. ${ }^{129}$ These smart contracts would use the technology that is part of electronic currencies, like bitcoin, to ensure automatic transfer of funds automatically. ${ }^{130}$

\section{CONCLUSION}

In Free Agent Nation, Daniel Pink observed: "The dream of America's young people? Not to climb through an organization, or even to accept a job at one, but to create their own gig on their own terms. ..." ${ }^{\prime 131}$ Free agency has its drawbacks-the specific example here is the problem of nonpayment. Yet free agency also has a certain allure. In an economy that has moved from industry to creativity, independence is the future of work. In fact, statistics ${ }^{132}$ suggest that we are already in that future.

Technology and private enterprise are evolving to meet the challenges of independence. Contracting norms and legal structures must also rise to meet the future by addressing the vulnerabilities of free agency. By encouraging written contracts, the Proposed Act in New York finds a delicate balance between private ordering and government mandate. Indeed, the proposed bill, which largely aims to protect the creative and highly skilled workers who have chosen independence, has the potential to raise the bar for all workers hired on a project basis.

While the proposed legislation has the potential to change the dynamic of client nonpayment, it fails to go far enough because it does not provide broader protections to the independent workforce. Legal reforms that aim to catch up with the naked economy need to re-imagine workplace law to reflect the changing workforce. Perhaps, more broadly, the key is redefining who is an employee or recognizing a new category of worker ${ }^{133}$ who is entitled to, among other things, the

129. Andrew Hinkes, Blockchains, Smart Contracts, and the Death of Specific Performance, INSIDE COUNSEL (July 29, 2014), http://www.insidecounsel.com/2014/07/29/blockchains-smartcontracts-and-the-death-of-speci.

130. See id.

131. PINK, supra note 1, at 14 .

132. See, e.g., InTUIT, TWENTY TREnds That Will Shape THE NEXT DeCADE 20 (2010), available at http://httpdownload.intuit.com/http.intuit/CMO/intuit/futureofsmallbusiness/intuit_2020_report.pdf. ("[R]oughly 25-30 percent of the U.S. workforce is contingent, and more than 80 percent of large corporations plan to substantially increase their use of a flexible workforce in coming years.").

133. See Befort, supra note 5, at 173; Wolfgang Daubler, Working People in Germany, 21 
protections of government mandates like the Fair Labor Standards Act and anti-discrimination legislation. (2013). 


\section{'}

